\title{
REVIEW \\ Hillary Kaell \\ Walking Where Jesus Walked: \\ American Christians and Holy Land Pilgrimage
}

(New York and London: New York University Press, 2014), paperback, xiii +269 pp.

Caitlin Carenen, Eastern Connecticut State University

In Walking Where Jesus Walked: American Christianity and Holy Land Pilgrimage, Hillary Kaell uses a broad subjecttwenty-first century Holy Land pilgrimage-to examine a deeply personal issue-faith and relationships of modern pilgrims. Three seemingly paradoxical themes emerge in her analysis: how pilgrims center their identity while traveling (home / away); how pilgrims balance the spiritual nature of the pilgrimage against the physical locality of the Holy Land (transcendent / material); and how pilgrims react to the lucrative business that is pilgrimage with the a-materiality of religion (religion / commerce). These three themes are then further examined through two lenses: the personal and institutional / cultural. In Walking Where Jesus Walked, Kaell offers a new approach to modern pilgrimage studies by going beyond the pilgrimage itself to examine the pre- and post-travel experiences of pilgrims. Ultimately, Kaell argues that the juxtaposition of seemingly contradictory impulses make the pilgrimage "spiritually powerful" and can help the pilgrim "grapple with what it means to be a Christian in the Holy Land today" and what it means to be a Christian in America (p. 5).

Kaell, a religious studies scholar and ethnographer, conducted interviews with pilgrims before, during, and after their travels. This provides a rich perspective on the complex layers of contemporary American Christian identity in a globalized world. The central question she asks is how contradictory impulses found in modern-day Holy Land pilgrimage can be under- 
stood in the context of twenty-first century American Christianity. Indeed, the strength of this book lies in her refusal to separate the home / American experience from the journey itself and vice-versa.

She examines the paradoxical theme of home "material" / away "imagined" (in other words, the reality / physicality of home versus imagined travel). Kaell concludes that in order to stabilize or improve relationships at home, pilgrims visit the Holy Land. They do not seek new spiritual experiences (especially those that might challenge their evangelical or Catholic beliefs), but rather seek to affirm or deepen existing belief. Moreover, in interrogating the duality of transcendence / materiality, she discovers that pilgrims, particularly women, "refract" the Arab-Israeli conflict through a moral / religious lens and tend to eschew political engagement (p. 202). Instead, they focus on the so-called "living stones"-the Holy Land residents (Israeli Jews, Messianic Jews, or Palestinian Christians) who offer a spiritual connection to the "biblical pastoral" world and even to Jesus (p. 202). Fear of the travel experience comes less from potential violence in the region and more from fear of disappointment with the experience itself (i.e. will it provide whatever transformation or change the pilgrim personally seeks?). One particularly interesting conclusion Kaell offers is that Catholics are growing more interested in a personal relationship with Jesus and practicing home devotional studies, while evangelicals have begun to embrace the sensory experience of pilgrimage. Such conclusions reflect her contribution to our understanding of twenty-first century Christianity and its continuing evolution.

Finally, in examining the religion / commerce paradox, Kaell concludes that pilgrims brand non-familiar practices as "commercialized" even as they use commercial experiences to justify their own, familiar practices (pp. 128, 130). Gender plays a role in understanding how "middle-old" female pilgrims frame their decisions to spend money to take a pilgrimage. As Kaell notes in her conclusion, "by purchasing tourism and souvenirs, pilgrims see themselves as doing and 
giving," while remaining within the confines of "gendered discourses of antimaterialism born of female sacrifice” (p. 205). The religious / commerce theme also suggests another paradox: the pilgrimage is for personal edification even as it strengthens the (mainly) female pilgrim to resume the role of primary caregiver once she returns home. Also (perhaps as a side-note), the analysis of the religious / commerce theme offers a new perspective on the generally adroit Israeli approach to promoting Christian tourism in Israel. On the other hand, Kaell's examples of clashes between Israeli tours and American Christians' expectations and desires, for example, provided some of the most colorful and interesting parts of the book.

Walking Where Jesus Walked, by extending the research to before and after a pilgrimage, serves as a methodological correction to previous research that focused simply on the trip. Also, Kaell includes a group of pilgrims neglected in recent literature, American Catholics. In so doing, Kaell complicates the existing narrative that places Catholics in an outdated dichotomy ("devotional foil to evangelicals' biblicism" [p. 203]). Another strength of her work is that it is deeply grounded in theory, including pilgrimage theory, and multi-disciplinary (drawing on material cultural studies, religious studies, anthropology, and sociology) and yet it remains generally accessible to a wide audience. She engages concepts of lived religion that examine global influences, even while recognizing that the participants do not view themselves as "implicated in global processes" and instead insist on a more localized selfidentification of themselves (p. 201). Kaell's willingness to engage pilgrims with sincerity (something missing in some other studies using similar methodologies) is refreshing and strengthens her analysis.

On a minor note, the subtitle makes the claim that this assessment addresses American Christians in general. Yet the study very clearly focuses only on Catholics and evangelicals, not on mainline Protestants. Kaell makes references to mainline Protestants at different points throughout the book (often 
grouping them with Catholics, particularly in the context of approaches to Palestinians), but only really examines Catholics and evangelicals. This approach led this reviewer to wonder what evidence compelled Kaell to make such generalizations about mainline Protestants. This is a question of methodology more than the accuracy of her assessment. There were also minor mistakes that perhaps reflect brief moments of theological confusion (for example, a Methodist is unlikely to pray to Jesus' mother Mary [p. 91]). Finally, while Kaell's dual lenses of personal and institutional / cultural are consistent throughout the book, proportionally she is far stronger in offering analysis of the personal experiences of the pilgrims. It is clear that this is what is most fascinating to her (perhaps owing to the time she spent accompanying groups on their pilgrimages).

Frankly, this (over) emphasis, while perhaps a weakness, nonetheless makes Walking Where Jesus Walked a pleasurable read. Kaell's research seamlessly blends theory and lived religion, and her illustrative examples from her interviews and observations cogently re-enforce her conclusions. For this reason, Walking Where Jesus Walked would find a ready audience in graduate courses in religion, religious history, sociology, and anthropology as well as among non-specialists. 